\title{
Review on PGPR: An Alternative for Chemical Fertilizers to Promote Growth in Aloe vera Plants
}

\author{
Meena $^{1}$, Kusum Narwal ${ }^{1}$, Nayan Tara ${ }^{2 *}$ and Baljeet Singh Saharan ${ }^{1}$ \\ ${ }^{1}$ Microbial Resource Technology Laboratory, Department of Microbiology, Kurukshetra \\ University Kurukshetra-136119, India \\ ${ }^{2}$ Department of Bio and Nanotechnology, Guru Jambeshwer University of Science and \\ Technology, Hisar-125004, Haryana, India
}

*Corresponding author

\section{A B S T R A C T}

\begin{tabular}{|l|}
\hline K e y w o r d s \\
PGPR, \\
Rhizosphere, \\
Medicinal plant, \\
Aloe vera
\end{tabular}

\section{Introduction}

Demand for medicinal plants is increasing worldwide due to growing recognition of natural products. Allopathic medicine also owes a tremendous debt to medicinal plants: one in four prescriptions filled in a country like India is either a synthesized form of or derived from plant materials. Habitat loss and deforestation coupled with over harvesting has resulted in dwindling population of important medicinal plants. Therefore, direct extraction of natural products from wild medicinal plants to satisfy the current requirement is fast becoming an unrealistic goal. Domestic cultivation of medicinal plants is thought as a viable alternative. But, certain drawbacks, including variability in yield and difference in phytochemical profile over wild one are making it as a last resort. Mediculture, the scientific cropping of industrially important medicinal plants, has become the need of the day to improve the productivity of the medicinal important plants such as Aloe vera. Aloe vera is a unique medicinal plant having large applications in medical and cosmetic industries. Aloe vera gel includes more than 75 biologically active substances 
such as vitamins, anthraquinones, minerals, enzymes, sugars, lignin, saponins, sterols, amino acids and salicylic acid. The gel present in the leaf pulp of Aloe vera is used for curative purposes and yellow latex present in bundle sheath cell is used for cathartic purposes. Thus, demand for this miraculous plant is increasing in both domestic and international markets (Rodríguez and Fraga, 1995). Hence, the quest to find a mechanism to increase its production is fundamental. Although much research has been conducted on the effect of PGPR on the crops, very little work has been done with medicinal plants. This field constitutes a largely unexplored method to increase productivity of medicinal plants.

Aloe barbadensis Miller (Aloe vera) is a perennial plant of the lily (Liliaceae) or Aloeaceae family. It is a stemless or very short-stemmed succulent plant growing to 80$100 \mathrm{~cm}$ tall, spreading by offsets and root sprouts. Aloe gel is the colourless gel contained in the inner part of the fresh leaves (Reynolds and Dweck, 1999). The gel consists primarily of water $(>98 \%)$ and polysaccharides (pectins, cellulose, hemicellulose, glucomannan, acemannan and mannose derivatives). Acemannan is considered the main functional component of Aloe vera and is composed of a long chain of acetylated mannose (Femenia et al., 1999; Djeraba and Quere, 2000; Lee et al., 2000). It contains almost $95 \%$ of water, more than 70 essential medicinal ingredients including mineral, enzymes, proteins, amino acid, vitamins, vitamin $\mathrm{B}_{12}$ and polysaccharides. These all combines and make Aloe vera plant really beneficial. Aloe vera juice is used in relieving digestive problems. Aloe vera acts as an antibacterial agent and protects the skin of a person against the sun's ultraviolet rays. It increases the flow of blood to the areas of wound and enhances fibroblasts. Gel is the pulp of the leaf and juice is obtained by homogenizing and diluting the gel. Aloe gel is the new wonder anti-ageing agent. Gel is widely used in various medical, cosmetic and neutraceutical applications (Ni et al., 2004). Aloe vera gel is helpful in case of minor cuts, scrapes and bruises and provides relief to a person rapidly. Aloe vera gel has provided a number of benefits to a person such as it helps in healing the sores and blisters and also helps people suffering from Psoriasis by reducing the itching and pain. It has shown considerable improvement in the reduction of lesions. Ample of study has been done for Aloe vera which aid in fighting against the cancer. It has also been confirmed that Aloe vera gives relief to the people suffering from liver problems, gastric problems and inflammatory bowel disease. Aloe vera gel is used both, topically (treatment of wounds, minor burns, and skin irritations) and internally to treat constipation, coughs, ulcers, diabete, headaches, arthritis, immune-system deficiencies (Vogler and Ernst, 1999; Eshun and He, 2004).

In addition to pharmaceutical importance, Aloe vera is widely used in food beverage and cosmetic industry. In the food industry, Aloe is being used as an ingredient for functional foods, mainly as food supplements the development of health drinks, desserts and beverages. In the recent past, the plant has emerged as an important commercial item. Aloe vera gel is used as an ingredient in commercially available yogurt, beverages and some desserts (Reynolds, 2004).

\section{Plant Growth Promoting Rhizobacteria}

Plant Growth - Promoting Rhizobacteria (PGPR) are a group of microorganisms that are able to colonize the rhizosphere or roots of many plant species, conferring beneficial effects on their host (Kloepper et al., 1981). The PGPR present around the roots of the plants encourages beneficial effects on plant 
health and growth, suppress disease-causing microbes and accelerate nutrient availability and assimilation. The use of microorganisms with the aim at improving nutrient availability for plants is an important practice and is necessary for agriculture (Kloepper et al., 1981; Backman and Sikora, 2008). During the past couple of decades, the use of PGPR for sustainable agriculture has increased tremendously to various parts of the world. Significant increase in growth and yield of agronomical important crops in response to inoculation with PGPR has been repeatedly reported (Amara and Dahdoh, 1997; Chanway, 1998; Pan et al., 1999; Bin et al., 2000; Gupta et al., 2000; Asghar et al., 2002; Vessey, 2003; Silva et al., 2004; Araujo et al., 2005; Figueiredo et al., 2007; Zhang et al., 2010). In accordance with Vessey (2003), soil bacterial species burgeoning in the plant rhizosphere which grows in, on, or around plant tissues, stimulate plant growth by a plethora of mechanisms is collectively known as PGPR.

\section{Bioactive factors produced by PGPR}

Bioactive factors are substances that impact on growth of plants such as root exudates, vitamins, amino acids and phytohormones. Such products can affect rhizosphere properties and hence availability of soil nutrient by altering rhizosphere $\mathrm{pH}$ and the activity of microbes including PGPR.

\section{Isolation of bacteria from Aloe vera PGPR}

Herminiimonassax obsidens was isolated by Nongkhlaw and Joshi in 2013 from subtropical forests of Meghalaya, India. Their study was an attempt to explore plant associated bacteria which are beneficial to host plants, and thus aid in the conservation of ethnomedicinal plants of the studied subtropical forests, which are dwindling due to exploitation. Rai et al., 2017 isolated three hundred seven fluorescent Pseudomonas isolates from the Aloe barbadensis (Miller) rhizosphere. Mamta et al., 2013 isolated four phosphate solubilizing bacteria identified as Pseudomonas synxanthaI AM 12356 for A1; Burkholderia gladioli R406 for A6 Enterobacter hormaechei EN 314 for A20 and Serratia marcescens A3 for A51 isolate. Meena et al., 2013 isolated four plant growth promoting rizobacteria from Aloe vera rhizosphere as Acinetobacter radioresistens SMA4, Bacillus thuringiensis SMA5, Brevibacterium frigrotolerans SMA23 and Pseudomonas fulva SMA24.

\section{Phosphorus solubilization}

Phosphorus is an essential macronutrient for growth and development of plants involved in important metabolic pathways like photosynthesis, biological oxidation, nutrient uptake and cell division (Illmer and Schinner, 1992). Mamata et al., 2013 found the amount of P-solubilization by PSB varied from 150 to $340 \mu \mathrm{g} \mathrm{ml}^{-1}$.

Maximum $\mathrm{P}$ solubilization was observed by A1 $\left(340 \mu \mathrm{g} \mathrm{ml}^{-1}\right)$ followed by A6 $(276 \mu \mathrm{g}$ $\left.\mathrm{ml}^{-1}\right)$, A51 $\left(212 \mu \mathrm{g} \mathrm{ml}^{-1}\right)$ and A20 (150 $\mu \mathrm{g}$ $\left.\mathrm{ml}^{-1}\right)$. Karthikeyan et al., 2010 observed that the microbial population is more in the rhizosphere soil compared to non-rhizosphere soil of the medicinal plants.

Meena et al., (2017) observed phosphorus solbilization in range of $82.9 \mathrm{mg} \mathrm{L}^{-1}-135.6 \mathrm{mg}$ $\mathrm{L}^{-1}$ isolated from Aloe vera rhizosphere. Radhika and Rodrigues (2010) isolated $G$. maculosum, G. multicaule, G. geosporum from Aloe vera which were potent phosphate solubilizer. Based on partial 16S rRNA gene sequencing PSB were identified as Pseudomonas putida, Pseudomonas sp. and Pseudomonas plecoglossicida with highest phosphate solubilization ability (Rai et al., 2017). 


\section{IAA production}

Phytohormone production is one of the important trait of PGPR. Among the phytohormones, indole-3-acetic acid (IAA) is the naturally occurring and most physiologically active auxin found in plants. IAA is released as a secondary metabolite because of the rich supplies of substrates exuded from the roots (Srrzelczyk and Pokojska, 1984; Ahmad et al., 2005). Microbial biosynthesis of IAA in soil are enhanced by tryptophan secreted from roots or decaying cells (Benizri et al., 1998) and its positive effect on root growth and morphology is believed to increase the access to more nutrients in the soil and enhancing other beneficial bacteria or fungi, controlling fungal diseases, controlling bacterial diseases (Bioprotectant). Mamta et al., 2011 observed Isolate A6, A20 and A51 produced IAA $6.93 \mu \mathrm{g} \mathrm{ml}^{-1}, 4.33 \mu \mathrm{g} \mathrm{ml}^{-1}, 28.2 \mu \mathrm{g} \mathrm{ml}^{-1}$ respectively). Whereas, isolate $\mathrm{A} 1$ produced no IAA. Meena et al., (2017) observed Maximum IAA production was shown by isolate SMA24 $\left(80.2 \mu \mathrm{g} \mathrm{mL}^{-1}\right)$ followed by SMA23 $(66.4 \mu \mathrm{g}$ $\left.\mathrm{mL}^{-1}\right)$, SMA5 $\left(53.8 \mu \mathrm{g} \mathrm{mL}^{-1}\right)$ and SMA4.34.6 $\mu \mathrm{g}$ $\mathrm{mL}^{-1}$. Malleswari. D and Bagyanarayana, 2013 observed that isolate Av 30 isolated from Aloe vera rhizosphere produced $60.0 \mu \mathrm{g} \mathrm{mL}^{-1}$ IAA.

\section{Siderophore production}

Siderophore are iron chelating compounds produced by plant growth promoting bacteria having high association constants for complexing iron. Meena et al., 2017 observed quantitative estimation, maximum siderophore percentage units were observed in case of SMA5 followed by SMA24, SMA23 and SMA4. SMA23 and SMA24 has shown maximum siderophore production (38.6\% Siderophore units and $41.6 \%$ Siderophore units) after an incubation time of $36 \mathrm{~h}$ and $48 \mathrm{~h}$ respectively while in case of SMA4 maximum siderophore production $(21.6 \%$ Siderophore units) was observed after incubation time of 72h. Isolates, A1, A6, A20 and A51 produced siderophore $94.47 \%, 95.22 \%, 27.86 \%$ and $86.67 \%$ respectively.

\section{Effect of PGPR on Aloe growth}

Mamta et al., 2013 observed that PGPR significantly $(\mathrm{P} \leq 0.05)$ increased leaf length by $39.5 \%$, root length by $31.1 \%$, total number of leaves by $48.1 \%$,total gel volume by $143 \%$, dry gel weight by $147 \%$ and dry rindweight by $95.2 \%$ as compared to the control plants. Maximum stimulatory effects on various biometric parameters were obtained by $P$. synxantha followed by $S$. marcescens, $B$. gladioli and $E$. hormaechei. Compared to control plants, an increase of over $243 \%$ in total gel volume was observed in plants treated with the PSB consortium. Maximum increase in leaf length $(21.0 \%)$ and dry rind weight (51.8\%) was shown by $P$. synxantha treated plants. Whereas, in case of root length, total gel volume and dry gel weight, maximum stimulatory effects were shown by $S$. marcescens treated plants. The plants treated with B. gladioli and E. hormaechei showed smaller increases in growth parameters than $P$. synxantha and $S$. marcescens treated plants. Meena et al., 2017 observed that PGPR SMA5 significantly $(\mathrm{P} \leq 0.05)$ increased Plant biomass by $105.72 \%$, root weight by $111.67 \%$, shoot weight by $137.23 \%$, total number of leaves weight by $63.23 \%$, total gel volume by $193 \%$ as compared to the control plants. Compared to control plants, an increase of over $213 \%$ in total gel volume was observed in plants treated with the consortium.

\section{Effect of PSB on aloin-A content}

The increase in the aloin-A content was due to both the increase in biomass of Aloe plants and the increased biosynthesis of aloin-A as compared to control plants. The increases were $159 \%$ and $673 \%$ based on $\mathrm{g}^{-1}$ dry gel weight basis and plant $^{-1}$ dry gel weight basis, respectively. Amongst individual PSB treatments, a maximum increase (90.4-111\%, g-1 dry gel weight and 245-293\%, plant ${ }^{-1}$ dry gel weight) was observed with $\mathrm{P}$. synxantha treated plants in both soil. Meena et al., (2017) observed that Amongst individual PGPR treatments, a maximum increase $184 \%$ was 
observed with $P$. fulva treated plants followed by Bacillus thuringiensis SMA5 (152.6\%).

The present review clearly indicates the potential of plant growth promoting rhizobacteria on Aloe plant growth and aloin-A content. The effect of an inoculation by a consortium was more pronounced than individual inoculations. This review also demonstrates that increased nutrient uptake in plants directly correlates with enhanced aloin-A production. This review emphasizes the potential of an economical and eco-friendly means of achieving higher levels of aloin-A by using plant growth promoting bacteria. However, further research is needed to understand the specific mechanisms involved in the positive effects of PGPR on the biosynthesis of aloin-A contents

\section{Acknowledgement}

The financial support provided in form of JRF/SRF to Meena by Council of Scientific and Industrial Research (CSIR), Government of India is fully acknowledged.

\section{References}

Amara, M. A. T. and Dahdoh, M. S. A. 1997. Effect of inoculation with plant growthpromoting rhizobacteria (PGPR) on yield and uptake of nutrients by wheat grown on sandy soil. Egy. J. Soil, 37: 467-484.

Araujo, F. F., Henning, A. A. and Hungria, M. 2005. Phytohormones and antibiotics produced by Bacillus subtilis and their effects on seed pathogenic fungi and on soybean root development. World $J$. Microbiol. Biotechnol., 21: 1639-1645.

Asghar, H. N., Zahir, Z. A., Arshad, M. and Khalig, A. 2002. Plant growth regulating substances in the rhizosphere: microbial production and functions. Adv. Agron., 62: 146-151.

Backman, P. A. and Sikora, R. A. 2008. Endophytes: an emerging tool for biological control. Biol. Control, 26: 1-3.
Bin, L., Smith, D. L. and Ping-Qui, F. 2000. Application and mechanism of silicate bacteria in agriculture and industry.Guizhou. Sci., 18: 43-53.

Bishwas, J. C., Ladha, L. K. and Dazzo, F. B. 2000. Rhizobia inoculation improves nutrient uptake and growth of low land rice. J. Soil Sci., 64: 1644-1650.

Chanway, C. P. 1998. Bacterial endophytes: ecological and practical implications. Sydowia., 50: 149-170.

Djeraba, A. and Quere, P. 2000. In vivo macrophage activation in chickens with Acemannan, a complex carbohydrate extracted from Aloe vera. Int. J. Immunopharmacol., 22: 365-372.

Eshun, K. and He, Q. 2004. Aloe vera: A valuable ingredient for the food, pharmaceutical and cosmetic industries A review. Crit. Rev. Food Sci. Nutr., 44: 91-96.

Femenia, A., Sanchez, E. S., Simal, S. and Rossello, C. 1999. Compositional features of polysaccharides from Aloe vera (Aloe barbadensis Miller) plant tissues. Carbohydrate Polymers, 39: 109-117.

Figueiredo, M. V. B., Burity, H. A., Martinez, C. R. and Chanway, C. P. 2007. Plant growth-promoting Rhizobacteria for improving nodulation and nitrogen fixation in the common bean (Phaseolus vulgaris L.). World J. Microbiol. Biotechnol., 24: 1187-1193.

Gupta, A., Gopal, M. and Tilak, K. V. 2000. Mechanism of plant growth promotion by rhizobacteria.Ind. J. Exp. Biol., 38: 856862.

Gupta, M., Kiran, S., Gulati, A., Singh, B. and Tewari, R. 2012. Isolation and identification of phosphate solubilizing bacteria able to enhance the growth and aloin-A biosynthesis of Aloe barbadensis Miller. Microbiol res., 167(6): 358-363.

Illmer, P. and Schinner, F. 1995. Solubilization of inorganic calcium phosphatessolubilization mechanisms. Soil Biol. Biochem., 27: 265-270.

Karthikeyan, B., Joe, M. M., Jaleel, C. A. and 
Deiveekasundaram, M. 2010. Effect of root inoculation with plant growth promoting rhizobacteria (PGPR) on plant growth, alkaloid content and nutrient control of Catharanthus roseus (L.) G. Don. Natura Croatica, 19(1): 205-212.

Kloepper, J. W. and Schroth, M. N. 1981. Relationship of in vitro antibiosis of plant growth promoting rhizobacteria to plant growth and the displacement of root microflora. Phytopathol., 71: 1020-1024.

Lee, K. Y., Weintraub, S. T. and Yu, B. P. 2000. Isolation and identification of a phenolic antioxidant from Aloe barbadensis. Free Radical Biol. Med., 28: 261-265.

Malleswari, D. and Bagyanarayana, G. 2013. Plant growthpromoting activities and molecular characterization of rhizobacterial strains isolated from medicinal and aromatic plants. IOSR $J$. Pharmacy Biol. Sci. (IOSR-JPBS), 6(6): 30-37.

Nongkhlaw, W., Mary, F. and Joshi, S. R. 2014. Epiphytic and endophytic bacteria that promote growth of ethnomedicinal plants in the subtropical forests of Meghalaya, India. Revista de biologia tropical, 62(4): 1295-1308.

Pan, B., Bai, Y. M., Leibovitch, S. and Smith, D. L. 1999. Plant growth promoting rhizobacteria and kinetic as ways to promote corn growth and yield in short season areas. Europian J. Agron., 11: 179-186.

Radhika, K. P. and Rodrigues, B. F. 2010. Arbuscular mycorrhizal fungal diversity in some commonly occurring medicinal plants of Western Ghats, Goa region. $J$. For Res. 21: 45-52

Rai, A., Rai, P. K. and Singh, S. 2017. Characterization of phosphate solubilizing fluorescent pseudomonads from the rhizosphere of Aloe vera (L.). Arch. Agron. Soil Sci., 1-9.

Reynolds, T. 2004. Aloes - The genus Aloe. In: Medicinal and Aromatic plants-Industrial Profiles (Hardman, R., ed.), CRC Press, Boca Raton, Florida, USA, vol. 38.

Reynolds, T. and Dweck, A. C. 1999. Aloe vera leaf gel: A review update. $J$. Ethnopharmacol., 68: 3-37.

Rodri'guez, H. and Fraga, R. 1999. Phosphate solubilizing bacteria and their role in plant growth promotion. Biotechnol. Adv., 17: 319-339.

Silva, H. S. A., Romeiro, R. S., Macagnan, D., Halfeld-vieira, B. A., Pereira, M. C. B. and Mounteer, A. 2004. Rhizobacterial induction of systemic resitance in tomato plants: non-specific protection and increase in enzyme activities. Biol. Cont., 29: 288-295.

Vessey, J. K. 2003. Plant growth-promoting rhizobacteria as biofertilizers. Plant Soil, 255: 571-586.

Vogler, B. K. and Ernst, E. 1999. Aloe vera: a systematic review of its clinical eff ectiveness. British J. Gen. Pract., 49: 823-828.

Zhang, H. W., Huang, Y., Shi, L. and Xu, F. S. 2009. Genotypic differences in phosphorus acquisition and the rhizosphere properties of Brassica napus in response to low phosphorus stress. Plant Soil, 320: 91-102.

\section{How to cite this article:}

Meena, Kusum Narwal, Nayan Tara and Baljeet Singh Saharan. 2018. Review on PGPR: An Alternative for Chemical Fertilizers to Promote Growth in Aloe vera Plants. Int.J.Curr.Microbiol.App.Sci. 7(03): 3546-3551. doi: https://doi.org/10.20546/ijcmas.2018.703.407 